\title{
PENGARUH MODAL PSIKOLOGI DAN KETERLIBATAN PEGAWAI TERHADAP KINERJA PEGAWAI DENGAN KEPUASAN KERJA SEBAGAI VARIABEL MEDIASI \\ (STUDI PEGAWAI POLITEKNIK ILMU PELAYARAN SEMARANG)
}

\author{
Adhi Prastistha Silen \\ Politeknik IImu Pelayaran Semarang \\ E-mail: adhi.pip.smg@gmail.com
}

\begin{abstract}
The research objective to be achieved to analyze the effect of psychological capital and employee involvement to job satisfaction in Seamanship Polytechnic Semarang. To analyze the effect of psychological capital, employee engagement and job satisfaction to employee performance in Seamanship Polytechnic Semarang. To analyze the effect of psychological capital and employee involvement to employee performance, moderated by Job Satisfaction in Seamanship Polytechnic Semarang In this study took the population in this study were employees of the Polytechnic Semarang Seamanship, amounting to 218 persons. Sampling with random sampling technique that randomly sampling 142 respondents. Based analyst who conducted the study concluded that psychological capital and employee involvement and significant positive effect on job satisfaction. Capital psychology, employee engagement and job satisfaction positive and significant impact on performance. Job satisfaction does not mediate the effect of psychological capital and employee involvement to employee performance.
\end{abstract}

Keywords: psychological capital, employee involvement, job satisfaction and employee performance. 


\section{Adhi Prastistha Silen}

\section{PENDAHULUAN}

\section{Latar Belakang}

Modal Psikologis diartikan sebagai keadaan psikologi individu yang positif yang dicirikan dengan (1) kepercayaan diri (self - efficacy) (2) menciptakan atribusi yang positif (optimism) (3) harapan di masa yang akan datang (hope) (4) daya tahan menghadapi tantangan (resiliency)

Keempat modal psikologi itu diyakini mampu berkontribusi positif dalam diri seseorang sehingga ia dapat berkinerja optimal. Pegawai dapat meghasilkan pekerjaan secara maksimal dan dapat mendukung organisasi dalam mencapai kesuksesannya. Keberadaan pegawai menjadi salah satu poin penting dalam jalannya suatu organisasi birokrasi. Berbagai pekerjaan operasional maupun manajerial akan terasa lebih ringan dengan adanya dukungan dari para pegawai. Oleh sebab itu sebuah organiasi perlu mengetahui seberapa besar keinginan pegawai untuk bekerja.

Keterlibatan atau partisipasi pegawai dalam aktivitas-aktivitas kerja penting untuk diperhatikan karena dengan adanya keterlibatan pegawai akan menyebabkan mereka mau dan senang bekerja sama, baik dengan pimpinan ataupun dengan sesama rekan kerja. Salah satu cara untuk meningkatkan partisipasi pegawai adalah dengan melibatkan mereka dalam berbagai kesempatan termasuk dalam pengambilan keputusan. Keterlibatan pegawai bisa memberi motivasi instristik kepada karyawan dengan cara meningkatkan peluang kerja, tanggung jawab dan keterlibatan dalam pekerjaan itu sendiri.

Keterlibatan pegawai adalah sejauh apa karyawan terlibat dalam pekerjaan mereka sehingga menguatkan komitmen mereka terhadap pekerjaan dan organisasi (Raymond A Noe dkk 2011). Keterlibatan pegawai mengacu pada sejauh apa para pegawai terlibat penuh dalam pekerjaannya dan kekuatan komitmennya terhadap pekerjaan dan organisasi. Para pegawai yang terlibat dalam pekerjaan dan berkomitmen terhadap organisasi akan bekerja untuk keungulan yang kompetitif organisasi dalam bentuk produktivitas yang tinggi, pelayanan yang lebih baik dan menurunkan tingkat perputaran karyawan.

Selain itu, Shuck dan Wollard (2010:103) dalam Shuck, et al (2011), mengemukakan bahwa keterlibatan pegawai merupakan proses kognitif individu secara emosional dan perilaku yang diarahkan menuju hasil yang diinginkan oleh organisasi. Penilitian Markos dan Sridevi (2010) menemukan bahwa keterlibatan merupakan prediktor terkuat dalam meningkatkan kinerja organisasi.

Untuk meningkatkan kinerja pegawai, organisasi perlu melakukan perbaikan kinerja. Faktor yang perlu diperhatikan oleh suatu organisasi di dalam perbaikan kinerja, Mathis dan Jackson (2006: 378) menguraikan beberapa faktor yang digunakan dalam mengukur kinerja pegawai, yaitu hasil kerja, kualitas hasil kerja, ketepatan waktu kehadiran dan kemampuan bekerjasama.

Kinerja pegawai akan maksimal manakala organisasi mampu mengelola pegawai di dalam organisasi tersebut dengan baik. Pegawai juga merupakan aset sebuah organisasi, pegawai harus dipelihara dan dikembangkan karena pegawai memiliki ketrampilan, kemampuan, 
emosi, keinginan, tuntutan, kebutuhan dan keterbatasan. Pegawai yang kurang mendapatkan perhatian dan pengembangan yang memadai dari organisasi dapat memicu munculnya penurunan kinerja pegawai.

Salah satu faktor yang mempengaruhi kinerja dari organisasi adalah kepuasan kerja pegawai. Menurut Dole and Schroeder (2001), kepuasan kerja didefinisikan sebagai reaksi dan perasaan seseorang terhadap tempat ia bekerja. Kepuasan kerja pegawai merupakan hal yang bersifat individual tentang perasaan seseorang terhadap pekerjaannya (Robins, 2007).

Locke dalam Fred Luthans (2006) memberikan definisi komprehensif dari kepuasan kerja yang meliputi reaksi atau sikap kognitif, alektif dan evaluatif dan menyatakan bahwa kepuasan kerja adalah keadaan emosi yang senang atau emosi positif yang berasal dari penilaian pekerjaan atau pengalaman kerja seseorang. Kepuasan kerja adalah hasil dari persepsi karyawan mengenai seberapa baik pekerjaan mereka memberikan hal yang dinilai penting.

Kepuasan kerja merupakan hal yang penting dimiliki oleh setiap orang dalam bekerja. Tingkat kepuasan kerja yang tinggi akan mempengaruhi seseorang dalam menyelesaikan pekerjaanya, sehingga tujuan organisasional dapat dicapai dengan baik. Kepuasan kerja pada dasarnya merupakan sesuatu yang bersifat individual. Setiap individu memiliki tingkat kepuasan yang berbeda-beda sesuai dengan sistem nilai yang berlaku pada dirinya. Makin tinggi penilaian terhadap kegiatan dirasakan sesuai dengan keinginan individu, maka makin tinggi kepuasannya terhadap kegiatan tersebut. Jadi secara garis besar kepuasan kerja dapat diartikan sebagai hal yang menyenangkan atau yang tidak menyenangkan dimana pegawai memandang pekejannya.

Pegawai yang terpuaskan pada semua organisasi, merupakan penyumbang terpenting pada keefektifan organisasi dan sukses jangka panjang organisasi. Sebaliknya, pegawai yang tak terpuaskan memberi kontribusi yang sedikit pada organisasi. Biasanya pegawai akan merasa puas atas pekerjaan yang telah dikerjakannya, apabila apa yang telah dikerjakannya itu dianggap telah memenuhi harapan dan dengan demikian akan menimbulakan motivasi untuk melakukan tindakan kearah pencapaian harapan tersebut, dan jika harapannya terpenuhi ia akan merasa puas.

Untuk mewujudkan cita-cita reformasi birokrasi tersebut maka seluruh Pegawai Politeknik IImu Pelayaran Semarang tidak terkecuali yang berada di Politeknik IImu Pelayaran Semarang dituntut untuk dapat meningkatkan kinerja pegawai. Peningkatan kinerja pegawai menjadi penting, karena profesionalitas pegawai pada era reformasi merupakan salah satu faktor yang dapat mendorong percepatan perubahan kinerja aparatur

\section{Rumusan Masalah}

Berdasarkan latar belakang masaalah yang telah dikemukakan di atas maka dapat dirumuskan masalah penelitian sebagai berikut:

1. Apakah Modal Psikologi berpengaruh terhadap Kepuasan Kerja?. 


\section{Adhi Prastistha Silen}

2. Apakah Keterlibatan Pegawai berpengaruh terhadap Kepuasan Kerja?

3. Apakah Modal Psikologi berpengaruh terhadap Kinerja Pegawai ?

4. Apakah Keterlibatan Pegawai berpengaruh terhadap Kinerja Pegawai ?

5. Apakah Kepuasan Kerja berpengaruh terhadap Kinerja Pegawai ?

6. Apakah Kepuasan Kerja memediasi pengaruh Modal Psikologi terhadap Kenerja Pegawai?

7. Apakah Kepuasan Kerja memediasi pengaruh Keterlibatan Pegawai terhadap Kinerja Pegawai ?

\section{Tujuan Penelitian}

Tujuan yang ingin dicapai dalam penelitian ini adalah:

1. Untuk menganalisis Modal Psikologi berpengaruh terhadap Kepuasan Kerja Pegawai Politeknik Ilmu Pelayaran Semarang.

2. Untuk menganalisis Keterlibatan Pegawai berpengaruh terhadap Kepuasan Kerja Pegawai Politeknik IImu Pelayaran Semarang .

3. Untuk menganalisis Modal Psikologi berpengaruh terhadap Kinerja Pegawai Politeknik IImu Pelayaran Semarang.

4. Untuk menganalisis Keterlibatan Pegawai berpengaruh terhadap Kinerja Pegawai Politeknik Ilmu Pelayaran Semarang.

5. Untuk menganalisis Kepuasan Kerja berpengaruh terhadap Kinerja Pegawai Politeknik Ilmu Pelayaran Semarang.

6. Untuk menganalisis Modal Psikologi berpengaruh kepada Kinerja Pegawai dimediasi oleh Kepuasan Kerja Pegawai Politeknik IImu Pelayaran Semarang.

7. Untuk menganalisis Keterlibatan Pegawai berpengaruh kepada Kinerja Pegawai dimediasi oleh Kepuasan Kerja Pegawai Politeknik IImu Pelayaran Semarang.

\section{Manfaat Penelitian}

\section{Manfaat Teoritis}

Bagi llmu Pengetahuan, Hasil penelitian ini diharapkan dapat memberikan sumbangan bagi perkembangan ilmu pengetahuan yang berkaitan dengan modal psikologi, keterlibatan pegawai yang berpengaruh terhadap kinerja pegawai dan kepuasan kerja. 
Bagi Penelitian Lain, Hasil penelitian data memberikan sumbangan yang berarti dan mendorong timbulnya minat bagi peneliti lain untuk melakukan penelitian lebih lanjut tentang berbagai dimensi dari kepuasan kerja dan kinerja pegawai, sehingga khasanah pengetahuan tentang modal psikologi dan keterlibatan pegawai khususnya dalam manajemen sumber daya manusia bertambah luas.

\section{Manfaat Praktis}

1. Hasil penelitian ini diharapkan dapat memberikan masukan kepada Politeknik IImu Pelayaran Semarang untuk melakukan peningkatan atau perbaikan kualitas sumber daya manusia dalam rangka peningkatan pelayanan kepada masyarakat.

2. Untuk menambah koleksi karya ilmiah dan semakin memahami faktor-faktor yang terkait dengan modal psikologi, keterlibatan pegawai, kinerja pegawai dan kepuasan kerja.

\section{LANDAAN TEORI}

\section{Pengembangan Hipotesis}

H1: Modal Psikologi berpengaruh positif terhadap Kepuasan Kerja

H2: Keterlibatan pegawai berpengaruh positif terhadap kepuasan kerja.

H3: Modal Psikologi berpengaruh positif terhadap Kinerja Pegawai.

H4 : Keterlibatan pegawai berpengaruh positif terhadap kinerja pegawai.

H5 : Kepusan Kerja berpengaruh Positif terhadap kinerja pegawai.

\section{Model Penelitian}

Model Grafis

Berdasarkan hipotesis yang telah dibentuk tersebut maka dapat digambarkan model penelitian sebagai berikut:

Desain grafis antar variabel

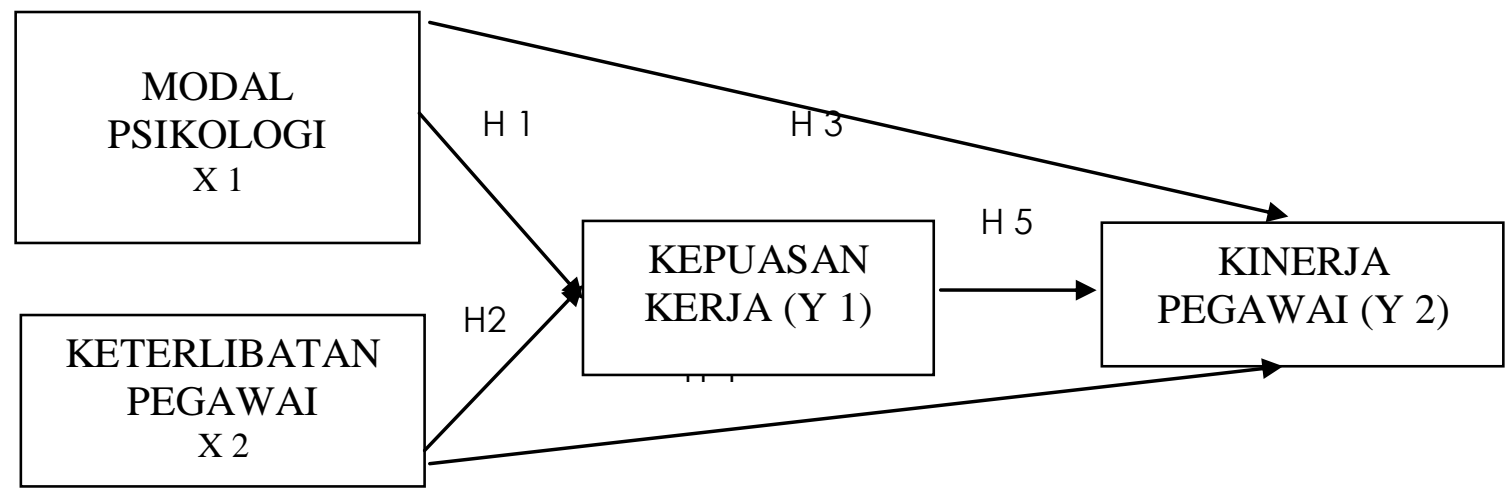




\section{Adhi Prastistha Silen}

Model Matematis

$Y_{1}=a_{1}+b_{1} X_{1}+b_{2} X_{2}+e_{1}$

$Y_{2}=a_{2}+b_{3} . X_{1}+b_{4} X_{2}+b 5 . Y_{1}+e_{2}$

Keterangan :

a : Konstanta

b : Koefisien Regresi Variabel Bebas (koefisien beta)

X1 : Variabel Modal Psikologi

X2 : Variabel Keterlibatan Pegawai

Y1 : Variabel Kepuasan Kerja

Y2 : Variabel Kinerja Pegawai

E $(1,2)$ : Disturbance Error

\section{METODE PENELITIAN}

\section{Jenis dan Sumber Data}

Penelitian ini menggunakan data uang diperoleh melalui responden, dimana responden memberikan repon verbal dan atau respon tertulis sebagai tanggapan atas pernyataan yang diberikan.

Adapun jenis data yang digunakan dalam penelitian ini adalah:

1. Data primer, adalah data mengenai pendapat responden tentang kompetensi, pengembangan karir, komitmen organisasional dan kepuasan kerja yang diperoleh secara langsung dari responden dengan memberikan tanggapan atas pernyataan kuesioner.

2. Data sekunder, adalah data yang diperoleh secara tidak langsung melalui perantara (diperoleh dan dicatat oleh pihak lain). Dalam penelitian ini data sekunder hanya mendukung pengumpulan data awal sebagai output penelitian.

\section{Populasi dan Sampel Penelitian}

Populasi menurut Sutrisno Hadi (2001) adalah sekumpulan dari seluruh elemen-elemen yang dalam hal ini diartikan sebagai obyek penelitian. Adapun populasi dalam penelitian ini adalah dosen dan karyawan Politeknikllmu Pelayaran Semarang yang berjumlah 218 orang.

Sampel adalah sebagian atau wakil populasi yang akan diteliti (Sutrisno Hadi, 2001). Sampel dalam penelitian ini adalah pegawai Politeknik IImu Pelayaran Semarang. Pengambilan sampel dengan teknik random sampling yang merupakan teknik pengambilan sampel 
secara acak. Oleh sebab itu penentuan jumlah sampel digunakan rumus slovin yang diperoleh 142 responden

\section{Metode Pengumpulan Data}

Metode pengumpulan data yang digunakan adalah dengan metode penyebaran kuesioner.

\section{Rencana Analisis Data}

Analisis Deskriptif

Analisis yang menguraikan data hasil penelitian tanpa melakukan pengujian, kemudian disajikan dalam bentuk tabel frekuensi dengan membuat pengelompokan dan prosentase nilai jawaban responden.

Analisis deskripsi meliputi :

1. Deskripsi Responden, Responden dalam penelitian ini sebanyak 82 orang yang dapat dikelompokkan secara statistik berdasarkan : Jenis Kelamin, Pendidikan, Status Kepegawaian dan Golongan kepangkatan, Masa kerja

2. Deskripsi Variabel, Deskripsi variable berupa perhitungan-perhitungan statistic, yang meliputi : Nilai rata-rata ( Mean ), Median, Modus, Nilai Minimum ( Min ), NilaiMaksimun( Maks ). Dengan deskripsi variable ini akan diperoleh gambaran kecenderungan jawaban seluruh responden terhadap suatu indicator pertanyaan.

\section{Uji Instrumen}

Uji Instrumen yang dianalisis dalam penelitian ini antara lain :

a. Uji Validitas, Uji validitas digunakan untuk mengukur sah atau valid tidaknya suatu kuesioner. Suatu kuesioner dikatakan valid jika pertanyaan pada kuesioner mampu untuk mengungkapkan sesuatu yang akan diukur oleh kuesioner tersebut (Ghozali;2011). Uji validitas dalam penelitian ini menggunakan Confirmatory Factor Analysis (CFA). Analisis faktor konfirmatori digunakan untuk menguji apakah suatu konstruk mempunyai undimensionalitas atau apakah indikator-indikator (autonom 1 sampai autonom 4) yang digunakan dapat mengkonfirmasikan sebuah konstruk atau variabel (Imam Ghozali, $2011)$. Dari analisis ini diketahui nilai rasio kecukupan sampel dengan melihat nilai KMO, dengan menggunakan analisis faktor maka item-item yang tidak valid akan dikeluarkan dari variabel penelitian. Faktor loading dilakukan dengan menggunakan analisis faktor dengan pada kolom correlation matrix. Item-item dalam penelitian bisa dianalisis lebih lanjut apabila nilai Kaiser Mayer Olkin (KMO) > 0,5 dan nilai signifikasi $<0,05$ atau $5 \%$. (Imam Ghozali 2011). Sedangkan untuk validitas masing-masing item dinyatakan valid apabila memiliki nilai loading factor / component matrix lebih besar dibandingkan 0,4.

b. Uji Reliabilitas, Realibilitas sebenarnya adalah alat untuk mengukur suatu kuesioner yang merupakan indikator dari variabel atau konstruk. Suatu kuesioner dikatakan realibel atau 


\section{Adhi Prastistha Silen}

handal jika jawaban seseorang terhadap pernyataan adalah konsisten atau stabil dari waktu ke waktu (Ghozali, 2011). Pengukuran realibilitas dalam penelitian ini dilakukan dengan pengukuran sekali saja atau disebut dengan One Shot. Penelitian ini mengukur realibilitas dengan uji statistik Cronbach Alpha (a). Nunnally (1994) dalam Ghozali (2011) menyatakan bahwa suatu konstruk atau variabel dikatakan reliabel jika memberikan nilai Cronbach Alpha $>0,70$.

\section{Analisis Regresi Berganda}

Uji Model

a. Uji Koefisien Determinasi, Ghozali (2011) Koefisien determinasi $\left(R^{2}\right)$ pada intinya mengukur seberapa jauh kemampuan model dalam menerangkan variasi variabel dependen. Nilai koefisien determinasi adalah nol dan satu. Nilai $R^{2}$ yang kecil berarti kemampuan variabel-variabel independen amat terbatas. Nilai yang mendekati satu berarti variabelvariabel indepeden memberikan hampir semua informasi yang dibutuhkan untuk memprediksi variasi variabel dependen.

b. Uji F (Uji Statistik F), Uji statistik F pada dasarnya menunjukkan apakah semua variabel independen atau bebas yang dimasukkan dalam model mempunyai pengaruh secara bersama-sama terhadap variabel dependen/terikat (Ghozali, 2011).

c. Uji Hipotesis (Uji †), Uji statistik † pada dasarnya menunjukkan seberapa jauh pengaruh satu variabel penjelas/independen secara individual dalam menerangkan variasi variabel dependen (Ghozali 2011). Uji † menggunakan regresi linier berganda untuk mengetahui hubungan kausal antara dua variabel bebas atau lebih terhadap satu variabel terikat tanpa melihat keeratan hubungan antar variabel bebas. Dalam menguji hipotesis penelitian, dibuat persamaan regresi linier berganda sebagai berikut:

$$
\begin{aligned}
& Y_{1}=a_{1}+b_{1} X_{1}+b_{2} X_{2}+e_{1} \\
& Y_{2}=a_{2}+b_{3} X_{1}+b_{4} X_{2}+e_{2}
\end{aligned}
$$

Keterangan :

$\begin{array}{ll}\text { A } & : \text { Konstanta } \\ \mathrm{b}_{1} & : \text { Koefisien Regresi Variabel Bebas (Koefisien beta) } \\ \mathrm{X}_{1} & : \text { Variabel Modal Psikologi } \\ \mathrm{X}_{2} & : \text { Variabel Keterlibatan Pegawai } \\ \mathrm{Y}_{1} & : \text { Variabel Kepuasan Kerja } \\ \mathrm{Y}_{2} & \text { : Variabel Kinerja Pegawai } \\ \mathrm{e}(1,2) & \text { : Disturbance Error }\end{array}$

d. Uji Efek Mediasi, Pengujian efekmediasi/intervening pada penelitian ini dengan membandingkan pengaruh langsung dan tidak langsung. Pengaruh langsung terjadi jika satu variable mempengaruhi lainnya tanpa ada variable ketiga yang memediasi kedua variable tadi. Pengaruh tidak langsung adalah jika ada variable ketiga yang memediasi hubungan kedua variable. Dalam penelitian ini, untuk menguji pengaruh 
variabel intervening menggunakan metodeanalisis jalur (path Analysis) dengan langkah-langkah sebagai berikut:

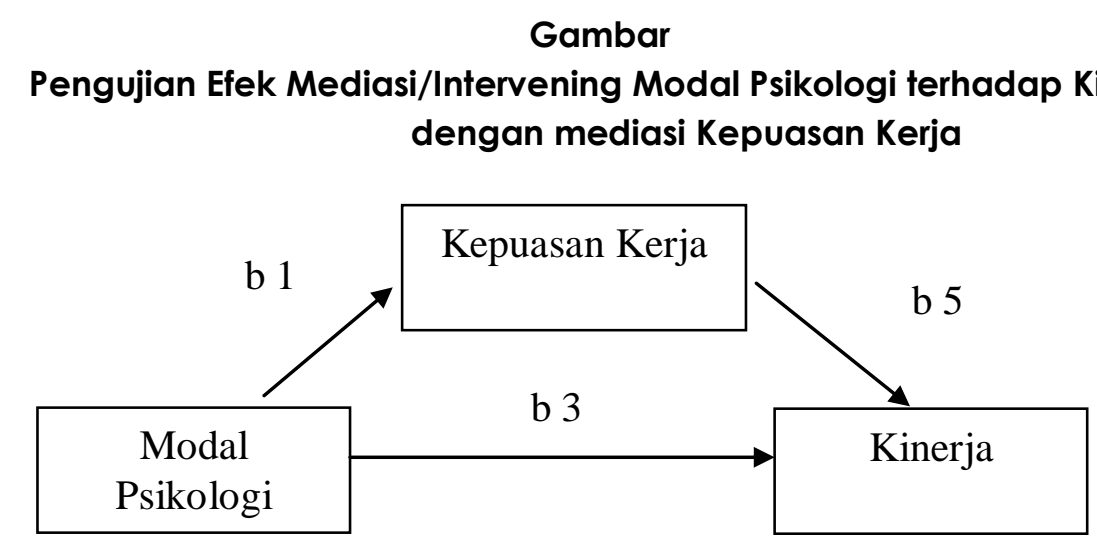

Syarat Mediasi apabila b $1 \times$ b $5>$ b 3 Kepuasan Kerja Memediasi Modal Psikologi terhadap Kinerja Pegawai, dan apabila b 1 x b5 < b3 Kepuasan Kerja tidak Memediasi.

Gambar

Pengujian Efek b Mediasi/Intervening Keterlibatan Pegawai terhadap Kinerja Pegawai dengan mediasi Kepuasan Kerja

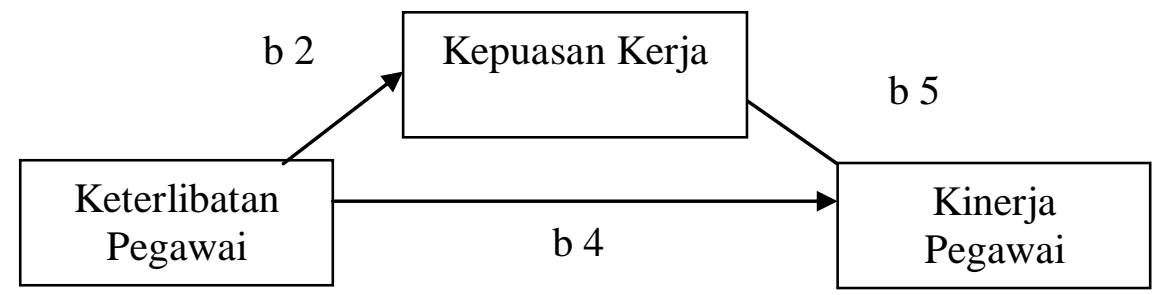

Syarat Mediasi apabila b $2 \times$ b $5>$ b 4 Kepuasan Kerja Memediasi Keterlibatan Pegawai terhadap Kinerja Pegawai dan apabila b 2 x b5 < b 4 Kepuasan Kerja tidak Memediasi

\section{HASIL PENELITIAN DAN PEMBAHASAN}

\section{Pengujian Hipotesis}

Pengujian hipotesis menggunakan uji secara parsial (uji t) untuk menguji pengaruh variabel independent terhadap variabel dependent secara parsial dengan kriteria taraf signifikan sebesar 0,05

1. Pengaruh modal psikologi $\left(X_{1}\right)$ dan keterlibatan pegawai $\left(X_{2}\right)$ terhadap kepuasan kerja $\left(Y_{1}\right)$ 
Tabel Hasil Uji Hipotesis

Pengaruh modal psikologi $\left(X_{1}\right)$ dan keterlibatan pegawai $\left(X_{2}\right)$ terhadap kepuasan kerja $\left(Y_{1}\right)$

\begin{tabular}{|c|l|c|c|l|}
\hline No & \multicolumn{1}{|c|}{ Variabel } & B & Signifikan & \multicolumn{1}{|c|}{ Keterangan } \\
\hline 1 & $\begin{array}{l}\text { Pengaruh modal psikologi } \\
\text { terhadap kepuasan kerja }\end{array}$ & 0,560 & 0,000 & $\begin{array}{l}\text { Ada pengaruh positif } \\
\text { dan signifikan }\end{array}$ \\
\hline 2 & $\begin{array}{l}\text { Pengaruh keterlibatan } \\
\text { pegawai terhadap } \\
\text { kepuasan kerja }\end{array}$ & 0,308 & 0,001 & $\begin{array}{l}\text { Ada pengaruh positif } \\
\text { dan signifikan }\end{array}$ \\
\hline
\end{tabular}

Sumber : Data primer yang diolah, 2016

a) Hasil hipotesis pertama modal psikologi menghasilkan koefisien regresi 0,560 dan tingkat signifikan 0,000 $<0,05$ sehingga secara parsial (individu) terdapat pengaruh positif dan signifikan terhadap kepuasan kerja. Dengan demikian hipotesis pertama (H1): Modal psikologi berpengaruh positif terhadap kepuasan kerja, diterima.

b) Hasil hipotesis kedua keterlibatan pegawai menghasilkan koefisien regresi 0,308 dan tingkat signifikan 0,001<0,05 sehingga secara parsial (individu) terdapat pengaruh positif dan signifikan terhadap kepuasan kerja. Dengan demikian hipotesis kedua (H2): Keterlibatan pegawai berpengaruh positif terhadap kepuasan kerja, diterima

2. Pengaruh modal psikologi $\left(X_{1}\right)$, keterlibatan pegawai $\left(X_{2}\right)$ dan kepuasan kerja $\left(Y_{1}\right)$ terhadap kinerja pegawai $\left(Y_{2}\right)$

Tabel Hasil Uji Hipotesis

Pengaruh modal psikologi $\left(X_{1}\right)$, keterlibatan pegawai $\left(X_{2}\right)$ dan kepuasan kerja $\left(Y_{1}\right)$ terhadap kinerja pegawai $\left(Y_{2}\right)$

\begin{tabular}{|c|l|c|c|l|}
\hline No & \multicolumn{1}{|c|}{ Variabel } & B & Signifikan & \multicolumn{1}{|c|}{ Keterangan } \\
\hline 1 & $\begin{array}{l}\text { Pengaruh modal psikologi } \\
\text { terhadap kinerja pegawai }\end{array}$ & 0,276 & 0,031 & $\begin{array}{l}\text { Ada pengaruh positif } \\
\text { dan signifikan }\end{array}$ \\
\hline 2 & $\begin{array}{l}\text { Pengaruh keterlibatan pegawai } \\
\text { terhadap kinerja pegawai }\end{array}$ & 0,262 & 0,021 & $\begin{array}{l}\text { Ada pengaruh positif } \\
\text { dan signifikan }\end{array}$ \\
\hline 3 & $\begin{array}{l}\text { Pengaruh kepuasan kerja } \\
\text { terhadap kinerja pegawai }\end{array}$ & 0,290 & 0,025 & $\begin{array}{l}\text { Ada pengaruh positif } \\
\text { dan signifikan }\end{array}$ \\
\hline
\end{tabular}

Sumber : Data primer yang diolah, 2016

a) Hasil hipotesis ketiga modal psikologi menghasilkan koefisien regresi 0,276 dan tingkat signifikan 0,031 < 0,05 sehingga secara parsial (individu) terdapat pengaruh positif dan signifikan terhadap kinerja pegawai. Dengan demikian hipotesis ketiga (H3): Modal psikologi berpengaruh positif terhadap kinerja pegawai, diterima

b) Hasil hipotesis keempat keterlibatan pegawai menghasilkan koefisien regresi 0,262 dan tingkat signifikan 0,021 $<0,05$ sehingga secara parsial (individu) terdapat pengaruh positif dan signifikan terhadap kinerja pegawai. Dengan demikian hipotesis keempat $(\mathrm{H} 4)$ : Keterlibatan pegawai berpengaruh positif terhadap kinerja pegawai, diterima

c) Hasil hipotesis kelima kepuasan kerja menghasilkan koefisien regresi 0,290 dan tingkat signifikan 0,025 $<0,05$ sehingga secara parsial (individu) terdapat pengaruh positif dan 
signifikan terhadap kinerja pegawai. Dengan demikian hipotesis kelima (H5): kepuasan kerja berpengaruh positif terhadap kinerja pegawai, diterima

\section{Uji Efek Mediasi}

1. Pengaruh variabel modal psikologi terhadap kinerja pegawai dengan mediasi kepuasan kerja digambarkan sebagai berikut :

\section{Gambar}

Path analysis pengaruh variabel modal psikologi terhadap kinerja pegawai dengan mediasi kepuasan kerja

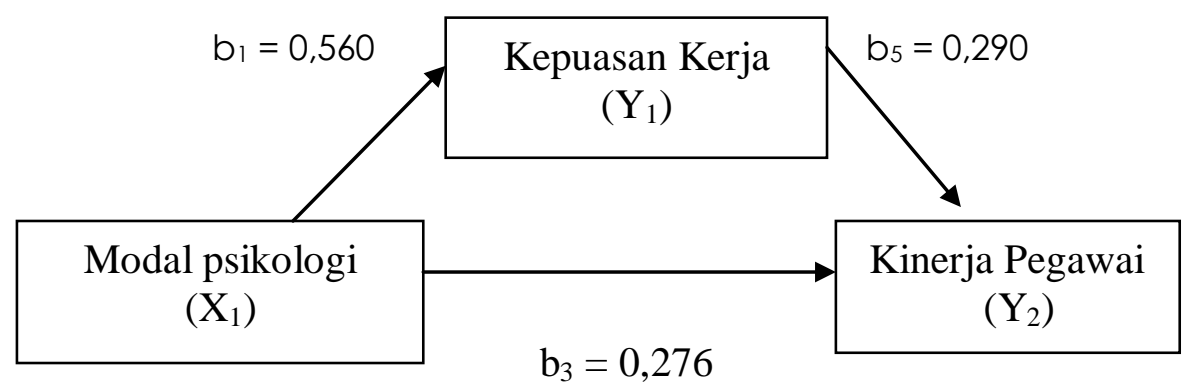

Berdasarkan gambar di atas dapat diketahui sebagai berikut :

1. Pengaruh langsung $\quad=0,276$

2. Pengaruh tidak langsung $=b_{1} \times b_{5}$

$=0,560 \times 0,290$

$=0,162$

Berdasarkan hasil tersebut di atas maka dapat disimpulkan bahwa pengaruh tidak langsung ( $b_{1} \times b_{5}$ ) sebesar 0,162 < pengaruh langsung 0,276 maka dikatakan kepuasan kerja tidak memediasi modal psikologi terhadap kinerja pegawai.

2. Pengaruh variabel keterlibatan pegawai terhadap kinerja pegawai dengan mediasi kepuasan kerja digambarkan sebagai berikut :

\section{Gambar}

Path analysis pengaruh variabel keterlibatan pegawai terhadap kinerja pegawai dengan mediasi kepuasan kerja

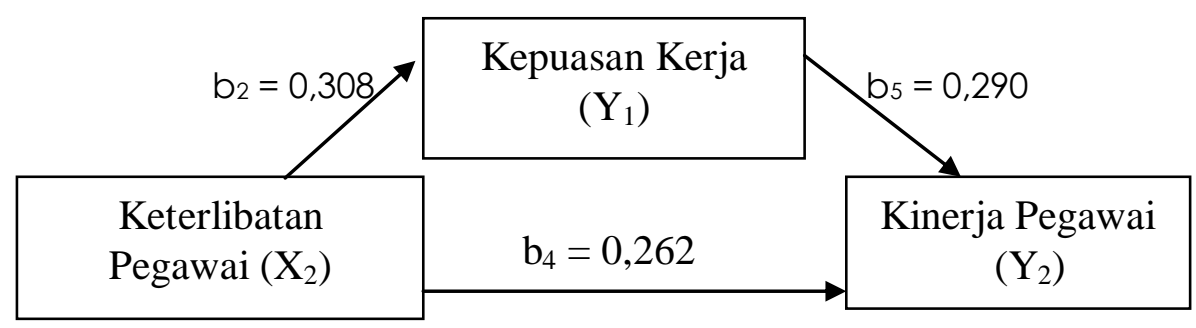




\section{Adhi Prastistha Silen}

Berdasarkan gambar di atas dapat diketahui sebagai berikut :

$$
\begin{aligned}
\text { 1. Pengaruh langsung } & =0,262 \\
\text { 2. Pengaruh tidak langsung } & =b_{2} \times b_{5} \\
& =0,308 \times 0,290 \\
& =0,089
\end{aligned}
$$

Berdasarkan hasil tersebut di atas maka dapat disimpulkan bahwa pengaruh tidak langsung $\left(b_{2} \times b_{5}\right)$ sebesar 0,089 < pengaruh langsung 0,262 maka dikatakan kepuasan kerja tidak memediasi keterlibatan pegawai terhadap kinerja pegawai.

\section{Pembahasan}

Penelitian yang dilakukan untuk mengetahui pengaruh modal psikologi dan keterlibatan pegawai terhadap kinerja pegawai dengan kepuasan kerja sebagai variabel mediasi pada pegawai Politeknik IImu Pelayaran Semarang adalah sebagai berikut :

1. Pengaruh modal psikologi dan keterlibatan pegawai terhadap kepuasan kerja

a. Modal psikologi menghasilkan koefisien regresi 0,560 dan tingkat signifikan $0,000<$ 0,05 sehingga secara parsial (individu) terdapat pengaruh positif dan signifikan terhadap kepuasan kerja. Hasil penelitian ini konsisten dengan hasil penelitian sebelumnya yang dilakukan oleh Fatih Cetin (2011) yang menghasilkan modal psikologi berpengaruh positif dan signifikan terhadap kepuasan kerja.

Modal psikologis diartikan sebagai keadaan psikologi individu yang positif yang dicirikan dengan kepercayaan diri (self - efficacy), menciptakan atribusi yang positif (optimism), harapan di masa yang akan datang (hope) dan daya tahan menghadapi tantangan (resiliency). Keempat modal psikologi itu diyakini mampu berkontribusi positif dalam diri seseorang sehingga ia dapat berkinerja optimal. Pegawai dapat meghasilkan pekerjaan secara maksimal dan dapat mendukung organisasi dalam mencapai kesuksesannya. Keberadaan pegawai menjadi salah satu poin penting dalam jalannya suatu organisasi birokrasi. Berbagai pekerjaan operasional maupun manajerial akan terasa lebih ringan dengan adanya dukungan dari para pegawai. Oleh sebab itu sebuah organiasi perlu mengetahui seberapa besar keinginan pegawai untuk bekerja

b. Keterlibatan pegawai menghasilkan koefisien regresi 0,308 dan tingkat signifikan $0,001<0,05$ sehingga secara parsial (individu) terdapat pengaruh positif dan signifikan terhadap kepuasan kerja. Hasil penelitian ini konsisten dengan hasil penelitian sebelumnya yang dilakukan oleh Deborah Christine Widjaja, dkk (2014) yang menghasilkan keterlibatan pegawai berpengaruh positif dan signifikan terhadap kepuasan kerja.

Keterlibatan pegawai mengacu pada sejauh apa para pegawai terlibat penuh dalam pekerjaannya dan kekuatan komitmennya terhadap pekerjaan dan organisasi. Para pegawai yang terlibat dalam pekerjaan dan berkomitmen terhadap organisasi akan bekerja untuk keungulan yang kompetitif organisasi dalam bentuk produktivitas yang tinggi, pelayanan yang lebih baik dan menurunkan tingkat perputaran pegawai. Keterlibatan pegawai pada pekerjaan di dalam organisasi 
tidak terlepas dari pegawai yang puas terhadap pekerjaanya. Semakin tinggi keterlibatan pegawai pada kerja organisasi akan semakin tinggi tingkat kepuasan kerja pegawai.

2. Pengaruh modal psikologi keterlibatan pegawai dan kepuasan kerja terhadap kinerja pegawai

a) Modal psikologi menghasilkan koefisien regresi 0,276 dan tingkat signifikan 0,031 < 0,05 sehingga secara parsial (individu) terdapat pengaruh positif dan signifikan terhadap kinerja pegawai. Hasil penelitian ini konsisten dengan hasil penelitian sebelumnya yang dilakukan oleh Nurina Vidya Lestari dan Fathul Himan (2013) yang menghasilkan modal psikologi berpengaruh positif dan signifikan terhadap kinerja pegawai.

Keberadaan pegawai menjadi salah satu poin penting dalam jalannya suatu organisasi birokrasi. Berbagai pekerjaan operasional maupun manajerial akan terasa lebih ringan dengan adanya dukungan dari para pegawai yang mempunyai modal psikologi yang tinggi. Semakin tinggi modal psikologi pegawai akan berdampak semakin tinggi kinerja pegawai tersebut.

b) Keterlibatan pegawai menghasilkan koefisien regresi 0,262 dan tingkat signifikan $0,021<0,05$ sehingga secara parsial (individu) terdapat pengaruh positif dan signifikan terhadap kinerja pegawai. Hasil penelitian ini konsisten dengan hasil penelitian sebelumnya yang dilakukan oleh Nurul Indayati, dkk (2011) yang menghasilkan keterlibatan pegawai berpengaruh positif dan signifikan terhadap kinerja pegawai.

Para pegawai yang terlibat dalam pekerjaan biasanya akan berkomitmen terhadap organisasi serta akan bekerja untuk keungulan yang kompetitif organisasi dalam bentuk kinerja yang tinggi. Semakin tinggi keterlibatan pegawai pada kerja organisasi akan berdampak pula pada semakin tingginya tingkat kepuasan kerja pegawai.

c) Kepuasan kerja menghasilkan koefisien regresi 0,290 dan tingkat signifikan 0,025 < 0,05 sehingga secara parsial (individu) terdapat pengaruh positif dan signifikan terhadap kinerja pegawai. Hasil penelitian ini konsisten dengan hasil penelitian sebelumnya yang dilakukan oleh Dian Kristianto, dkk (2011) yang menghasilkan kepuasan kerja berpengaruh positif dan signifikan terhadap kinerja pegawai.

Kepuasan kerja merupakan hal yang penting dimiliki oleh setiap orang dalam bekerja. Tingkat kepuasan kerja yang tinggi akan mempengaruhi seseorang dalam menyelesaikan pekerjaanya, sehingga tujuan organisasional dapat dicapai dengan baik. Pegawai yang terpuaskan merupakan penyumbang terpenting pada keefektifan organisasi dan sukses jangka panjang organisasi. Sebaliknya, pegawai yang tak terpuaskan memberi kontribusi yang sedikit pada organisasi. Biasanya pegawai akan merasa puas atas pekerjaan yang telah dikerjakannya, apabila apa yang telah dikerjakannya itu dianggap telah memenuhi harapan dan dengan 


\section{Adhi Prastistha Silen}

demikian akan menimbulakan motivasi untuk melakukan tindakan kearah pencapaian harapan tersebut, sehingga akan dapat mempengaruhi peningkatan kinerja pegawai.

\section{Uji Efek Mediasi}

a. Pengaruh variabel modal psikologi terhadap kinerja pegawai dengan mediasi kepuasan kerja. Dimana hasil penelitian bahwa pengaruh tidak langsung $x b_{5}$ ) sebesar 0,162 < pengaruh langsung 0,276 maka dikatakan kepuasan kerja tidak memediasi modal psikologi terhadap kinerja pegawai. Dengan kata lain modal psikologi lebih efektif berpengaruh langsung terhadap kinerja pegawai daripada melalui kepuasan kerja

b. Pengaruh variabel keterlibatan pegawai terhadap kinerja pegawai dengan mediasi kepuasan kerja. Di mana hasil penelitian bahwa pengaruh tidak langsung ( $\left.b_{2} \times b_{5}\right)$ sebesar 0,089 < pengaruh langsung 0,262 maka dikatakan kepuasan kerja tidak memediasi keterlibatan pegawai terhadap kinerja pegawai. Dengan kata lain keterlibatan pegawai lebih efektif berpengaruh langsung terhadap kinerja pegawai daripada melalui kepuasan kerja.

\section{KESIMPULAN}

Berdasarkan analisis data mengenai pengaruh modal psikologi dan keterlibatan pegawai terhadap kinerja pegawai dengan kepuasan kerja sebagai variabel mediasi pada pegawai Politeknik IImu Pelayaran Semarang Tengah dapat diambil kesimpulan sebagai berikut :

1. Modal psikologi berpengaruh positif dan signifikan terhadap kepuasan kerja

2. Keterlibatan pegawai berpengaruh positif dan signifikan terhadap kepuasan kerja

3. Modal psikologi berpengaruh positif dan signifikan terhadap kinerja pegawai

4. Keterlibatan pegawai berpengaruh positif dan signifikan terhadap kinerja pegawai

5. Kepuasan kerja berpengaruh positif dan signifikan terhadap kinerja

6. Kepuasan kerja tidak memediasi modal psikologi terhadap kinerja pegawai

7. Kepuasan kerja tidak memediasi keterlibatan pegawai terhadap kinerja pegawai

\section{DAFTAR REFERENSI}

As'ad, M (1998). Psikologi Industri, Liberty, Yogyakarta Bangun, Wilson ( 2012). Manajemen Sumber Daya Manusia, Penerbit Erlangga, Jakarta. Baumruk, R.,B.Gorman.2006. Why Managers are Crucial to Increasing Enggagement. Strategic HR Review, pp. 24-27 
Dole, Cole and Schroeder, Richard G.,2001. The Impact of Various Factors on The Personality, Job Satisfaction and Turnover Intention of Profesional Accounts. Managerial Auditing Journal, Vol. 16, No.4,p.234-245

Fandy.T.,dan Anatasia, D.2003. Total Quality Management (TMQ).Yogyakarta: Andi

Fred Luthans (2006). Perilaku Organisasi Edisi 20, alih bahasa ANDI Yogyakarta

Ghozali, Imam, (2011).Aplikasi Analisis Multivariate Dengan Program IBM SPSS 19, Semarang, Badan Penerbit Universitas Diponegoro

Hasibuan, M (2004). Manajemen Sumber Daya Manusia. Bumi Aksara, Jakarta

Khan, TI., Jam Ahmeed Farooq, Akbar Aisha, Khan Muhammad Bashir, dan Hijazi Syed Tahir.2011. Job Involvement as Predictor of Employee Commitment: Evidence from Pakistan. International Journal of Busines and Management Vol.6, No.4.hal.252-262

Luthans, F., Norman, S.M., Avolio, B.J., \& Avey, J.b.(2007). Positive Psychological Capital Measurement and Relationship with Performance and satisfaction. Personal Psychology, 60 (3), 541-572

Lewis, (2011). Positive Psychology at Work: How Positive Leadership and Preciateve Inquiry Create Inspiring Organizations. West Sussex : John Wiley \& Sons. Ltd

Mathis, Robert L, \& Jackson, John H (2006). Human Resource Management, alih bahasa Salemba Empat, Jakarta

Mangkunegara (2007). Manajemen Sumber Daya Manusia, Penerbit Erlangga, Jakarta

Mangkunegara (2010). Manajemen Sumber Daya Manusia, Penerbit Bandung Remaja Rosdakarya, Jakarta

Markos,S., dan Sridevi,M.S.2010. Employee Enggagement The Key to Improving Performance, International Journal of Business and Management, Vol.5 No. 12, Desember

Park, J., dan Gursoy. 2012, Generation Effects on Work Enggagement among US Hotel Employees. Internationl Journal of Hospitality Management, 1195-1202

Robbins P. Stephen (2002) Perilaku Organisasi, Konsep, Kontroversi, Aplikasi. Alih Bahasa, PT. Prehalindo, Jakarta

Robbins P. Stephen (2002). Perilaku Organisasi, PT.Indek Kelompok, Gramedia, Jakarta

Robbins SP, dan Judge. 2007. Perilaku Organisasi, Penerbit, Salemba Empat Jakarta

Raymond A.Noe, John R.Hollenback, Barry Gerhart, Patrick M Wright (2011). Manajemen Sumber Daya Manusia mencapai Keunggulan Bersaing, Penerbit Salemba Empat, Jakarta

Shuck, M.Brad.Rocco.T.S., dan Albonrnoz, C.E.( 2011). Employee Enggagement from the Employee Perspective:Implications for HRD; Journal of European Industrial Training, Vol. 35 No. 4hal 300-325

Sulistiyani, Ambat T \& Rosidah (2009). Manajemen Sumber Daya Manusia. Konsep, Teori \& Pengembangan dalam Konteks Organisasi Publik. Penerbit Graha IImu. Yogyakarta

Wexley, Kenneth N dan Gary A.Yukl (1997) Organizational Behavior and Personal Psychologi. Homewood, Illonois:Ricard D Irwin, Inc 